\title{
Where is the Framing Effect? Bridging the Gap between Theory and Data
}

\author{
Ryu, Jaesung
}

(Seoul National University)

$\langle$ CONTENTS〉

I. Introduction

II. Defining Frames

III. Mental Mechanisms Underlying Framing Effects

1. Accessibility

2. Associative Strength

3. Cognitive Engagement

4. Ambivalence
IV. Data

V. Findings

1. Framed versus Stripped Format

2. Alternative Frames Format

3. Competing Frames Format

VI. Explaining Non-Framing Effects

VII. Concluding Remarks

- Keyword: Framing Effects, Policy Judgments, Accessibility, Ambivalence, Cognitive Engagement, Associative Strength

\section{【ABSTRACT】}

This article documents failed framing attempts and addresses the question of under what condition framing effects occur. This study relied on the 1994 and 1998-9 Multi-Investigator Studies on Political Persuasion and Attitude Change, and the 1985 and 1989 National Election Studies Pilot Study. I found that framing effects are not as robust as previously thought, and that they are unusual across diverse political issues. Ordinary citizens are not at all ideological in Conversian terms, but are they competent at making decisions consistent with their belief system. I argue that framing effects appear more complex than current framing theories posit. Furthermore, I argue that framing theories need to be explicated and extended regarding how and when framing effects work, focusing on the underlying psychological mechanisms in terms of accessibility, ambivalence, cognitive engagement, and associative strength. 


\section{I . Introduction}

Framing effects constitute one of the most important concepts in the study of public opinion, mass communication, and media effects. Over the past decade, studies of framing effects have proliferated in political science, and framing effects have been documented in many issue areas(Druckman 2001a, 2001b, 2004; Druckman and Nelson 2003; Nelson, Oxley, and Clawson 1997; Nelson and Kinder 1996; Kinder and Sanders 1996; Kuklinski and Hurley 1994; Chong 1993; Nelson 2004). The validity of framing effects notwithstanding, recent research focuses on explicating the conditions necessary for framing effects. Druckman(2004) and Nelson(2004) find that framing effects vary in different conditions, with different framing strategies, and by individual dispositions. In addition, recent research suggests that we have been overwhelmed by successful framing attempts, so that the applicability or practical relevance of framing effects to the real political communications as well as to the study of opinion formation and change is overestimated. Indeed, framing effects that were once "an intriguing empirical anomaly" become "systematic," albeit by no means "universal," and are now considered "ubiquitous" and "prevalent"(Druckman 2004).

There has been an almost exclusive focus on statistically significant framing effects (Kuhberger et al. 1999). The policy issues analyzed to illustrate framing effects are chosen based on "higgledy-piggledy," so "without consideration ex ante of the principles properly governing the choice of the issue to be examined"(Sniderman and Theriault 2004, 142). Furthermore, null or disconfirming findings regarding framing effects are discarded and thus not reported, as will be shown in this paper.

Consequently, we may have misled ourselves in two ways. First, we have become convinced that framing effects are ubiquitous and prevalent. That is, due to the exclusive focus on successful framing effects, the possibility that a framing attempt can be successful is overestimated, although it might be a lot harder to shift the balance of opinion by framing issues. Second, theories of framing effects that account for the effects of political frames on public policy issues are based only on the successful framing attempts. This suggests that framing theories in political science might be a post hoc justification of the successful framing attempts rather than a systematic generalization of successful and failed framing attempts. In short, the conditions and factors that regulate framing effects are less studied.

This paper documents failed framing attempts that are unreported but still with us. This implies neither that framing effects are insignificant or irrelevant, nor argues that framing is an unnecessary feature of public discourse on matters of public policy. 
Instead, I believe that it is time to reconsider the context and parameters that regulate framing effects; thus to better understand such an important concept in the study of public opinion.

This paper relies on the 1994 and 1998-9 Multi Investigator Studies on Political Persuasion and Attitude Change(MIS) ${ }^{1)}$ and the 1985 and 1989 Pilot National Election Studies(NES). ${ }^{2)}$ These data sets have been considered major sources that demonstrate framing effects. Many reading scholars participated in collecting these data in order to test framing effects and to build theories of them(Zaller 1990; Kinder and Nelson 1990; Nelson and Kinder 1996; Sniderman et al. 1996). The data sets contain separate and independently conceived experiments over several policy issues that employed different framing formats.

I found considerable variances in the data sets examined in terms of the magnitude of framing effects across diverse policy issues: from "non-effects" to "choice shift" to "choice reversal." ${ }^{3)}$ From the analyses of this variability, it turns out that conditions necessary for framing effects are less frequent than generally assumed. To put it differently, framing an issue is a lot more difficult than framing theories suggest. This might be because: (1) not all political issues implicate the fundamental political values; (2) some political issues are not subject to framing effects; or (3) citizens are not as vulnerable to framing effects as is often supposed.

The paper first begins with a review of the literature on framing effects, discussing

1) Both surveys were carried out by the Survey Research Center of the University of California, Berkeley. In both surveys, telephone interviews based on computer-assisted telephone interviewing technology were conducted between June 1 and November 4, 1994 and between June 21, 1998 and March 7, 1999, respectively. In both studies, the survey population consisted entirely of English-speaking adults 18 years of age or older residing within the forty-eight contiguous U.S. states. In the 1998-9 study, 1,067 interviews were completed, and the response rate was $55.8 \%$. In the 1994 study, 1,464 interviews were completed, and the response rate was $65.5 \%$. Data sets and questionnaires used in these studies are available at http://sda.berkeley.edu, which is a home of a set of programs for the documentation and web-based analysis of survey data. For a detailed description of the sample and data collection methodology, see Sniderman, Brady, and Tetlock(1991).

2) The 1989 NES Pilot study took interviews over the telephone between July 6, 1989 and August 1, 1989, with 614 Americans of voting-age. A sample of 855 respondents who provided their telephone numbers in the pre and post election interviews in 1988 were selected, and $72 \%$ participated in the 1989 study.

3) "Non-framing effects," refers to no change in the distribution of opinions in the different experimental groups, which are exposed to the different frames. Both "choice shift" and "choice reversal" refer to a significant change in the distribution of opinions in response to the different frames. Nevertheless, choice reversal," yet not "choice shift," involves the change of the majority-minority distribution in response to the different frames; however, "choice shift" does not involve this change. 
the concept of frames and the mental mechanisms underlying framing effects. In the review I argue that the conceptual components that explain framing effects need to be more specifically spelled out. Next, the findings that show evidence of non-framing effects in several policy issues are presented. To account for the failed framing attempts as well as successful one, the factors that govern mental mechanisms of framing effects are discussed. Finally, a brief concluding section discusses the implications of the results and the suggestions for further study.

\section{Defining Frames}

Gamson and Modigliani(1987) define frames as "a central organizing idea or story line that provides meaning to an unfolding strip of events, weaving a connection among them"(143). Following this concept, frames are generally considered alternative descriptions or interpretations of the same information, problem or solution (Entman 1993; Sniderman and Theriault 2004; Jacoby 2000; Nelson 2004; Nelson and Kinder 1996; Nelson, Oxley, and Clawson 1997; Nelson and Oxley 1999). Simply put, frames emphasize "what the essential issue is and how to think about it"(Kinder 2003, 359). Given this definition, framing effects may arise "whenever there is more than one way to think about a subject"(Popkin 1983, 83); and framing strategies aim at casting qualitatively different yet potentially relevant considerations. For instance, the death penalty can be framed in various ways: "giving an eye for an eye justice for the criminals," "imposing discrimination against poor people and minorities," "unconstitutional" or "immoral."

Unlike "equivalency" or "valence" frames defined originally by Tversky and Kahneman (1981, 1987) and others(Levin, Schneider, and Gaeth 1998), ${ }^{4)}$ frames in politics are about alternative paths or considerations of policy goals attached to "values" rather than about contingency associated with "expected utility." Political debates can hardly be carried out in a logically equivalent way, which is, however, semantically different. As Sniderman and Theriault(2004) put it,

4) Framing refers to "the use of different, but logically equivalent, words or phrases of making the same statement (e.g., 5\% unemployment vs. 95\% employment). Framing strategy in this definition casts objectively identical information that is "logically equivalent but phrased in semantically different ways either in a positive or negative light." This type of frames induces psychological biases in the evaluation of outcomes and weight of probabilities because of the failures in assessing the logical equivalency that signifies the same expected utility among choice options. 
"certainly when it comes to the form in which alternatives are presented to citizens making political choices, it rarely is possible to establish ex ante that the gains(or losses) of alternative characterizations of a course of action are strictly equivalent. It accordingly should not be surprising that the concept of framing, for the study of political choices, typically refers to characterizations of a course of action in terms of an alternative "central organizing idea or story line that provides meaning to an unfolding strip of events"”(136).

In most political issues, making a choice among alternative options declares what ought to be thought about issues or what ought to be done. Nelson(2004) makes this point clear by claming that

by framing issues to emphasize one policy goal over another, communicators can affect the balance [that] citizens strike between competing values. This rearrangement in value priorities can subsequently affect policy opinions, even when beliefs about the issue remain unaltered(581).

Indeed, policy debates on, for instance, abortion, capital punishment, welfare programs, affirmative action, and others revolve on the central axes of the American values, such as individualism, meritocracy, egalitarianism, and range and latitudes of government power. In short, frames in politics are related to competing values that are embedded in alternative policy opinions.

\section{Mental Mechanisms Underlying Framing Effects}

\section{Accessibility}

Framing effects can occur by the manipulation of the accessibility to certain considerations regarding the issue at hand(Sniderman, Brody, and Tetlock 1991; Iyengar 1991; Kinder and Sanders 1996; Fazio and Olson 2003). Successful framing functions as an activator that highlights certain considerations, yet sidelines others in the opinion formation process. Framing attempts, therefore, would be successful if exposure to a frame makes accessible certain considerations invoked by the frame(Kinder and Sanders

5) Citation by the authors comes from Gamson and Modigliani(1987). 
1996; Nelson, Oxley, and Clawson 1997; Nelson 2004).

\section{Asseciative Strength}

It should be noted, however, that the accessibility is the key parameter only when individuals face one frame, not two or more. In fact, an exclusive presentation of one frame is not common in politics; competing frames are usually presented together and vie for importance or weight(see Sniderman and Theriault 2004). Framing theories posit that citizens facing rival frames are likely to put more or less weights on certain values (or facts or ideas) that are emphasized by the frames. Successful framing must function as an enhancer that helps people to easily and quickly retrieve certain preexisting attitudes or values inherent in their minds.

The question of which of preexisting values and attitudes prevail is determined by the associative strength between the information objects contained in the frames and their linkage to the values stored in one's memory(Fazio 1995). To the extent that an objectevaluation association is strong, that association is likely to be retrieved and adopted as one's response. Therefore, the associative strength determines which of rival frames will be prevalent when they vie for importance or weights in individuals' considerations (Eagly and Chaiken 1993; Fazio 1995).

\section{Cognitive Engagement}

In addition to the basic mechanisms mentioned above, other factors also determine the framing effects. Cognitive engagement including political knowledge and willingness to process political information carries weights. As Nelson(2004) notes, "the psychological keystone for many framing effects is the average citizens' notorious inability or unwillingness to think deeply about politics"(583). Individuals who possess the ability and motivation to expostulate on the issue at hand tend to engage in conscious, effortful processes and are therefore less likely to be susceptible to framing effects (Fazio 1995; Kuklinski et al. 2000; see also Chaiken and Trope 1999; Eagly and Chaiken 1993). As Druckman(2004) claims, deliberations through elite competition and citizens' interpersonal conversations invalidate framing effects.

Levels of cognitive engagement in responding to the frames must vary both by individual difference factors and across policy issues. Some issues are more salient in the public discourse, more relevant to individuals' personal life and considered more important for the country. These issues then attract more attention, which implies that 
individuals tend to pay attention to the frames that are related to salient, relevant and important issues. It follows that framing effects become less evident in salient, relevant, and important issues in which individuals engage in attentive information processing to shape their policy opinions in response.

\section{Ambivalence}

Evidence shows that individuals who have reasons for both supporting and opposing a course of action or feel ambivalent about how to think about a policy issue, are less likely to make a consistent choice and more likely to be swayed from one issue position to another(Chong 1993; Hochschild 1981; Zaller 1992; Feldman and Zaller 1992). To put it differently, frames that are unable to resolve the ambivalence inherent in policy issues by declaring which of the many considerations is relevant and important or should be given more attention are unlikely to be successful.

In the issues that have for a long time been controversial and in which values inherent are conflicted, individuals are likely to feel ambivalent, and vice versa. It follows that framing effects are less evident in the consensual issues in which there are no competing frames and most individuals hold strong opinion; in contrast, framing effects are more evident in the controversial issues in which there are competing frames and most individuals.

\section{Data}

The data used for this study are taken from the 1994 and 1998-9 Multi-Investigator Studies on Political Persuasion and Attitude Change and the 1985 and 1989 NES Pilot Study. In these data sets, respondents were randomly assigned to several groups in which they were asked the same question but with different emphases on issues. By framing issues in different ways, these studies were designed to test framing effects. According to the principal investigators of the 1989 NES Pilot Study(Zaller 1990; Kinder and Nelson1990), the major task was to test the hypothesis that "change in question frame can produce changes in the patterns of support for particular issues"(Zaller 1990, 1).

Several framing formats were utilized in these studies. In the "framed versus stripped format," respondents were randomly assigned to either a framed condition(i.e., a frame was presented) or stripped condition(i.e., no frame was presented $)^{6}$ to test the impacts of framed questions on opinions with reference to opinions in stripped questions. In the 
"alternative frames format," respondents were randomly assigned to one of two rival frames, or to one of two rival frames plus a stripped format to test the three methods of impact of each of rival frames and no frame on policy preferences. In the "competing frames format," respondents were simultaneously exposed to two rival frames to particularly test which of the rival frames prevail.

\section{Findings}

The best way in presenting the findings may be to let the data tell the story. I summarize the basic findings in Table 1, which shows failed framing attempts as well as successful ones.

First, Table 1 shows that framing effects are not evident in many issues. Only eight out of the twenty-five framing attempts $(31 \%)$ showed the expected framing effects. In other words, framing attempts in 17 issues failed to produce any changes in the distribution of opinion. This means that respondents expressed consistent policy preferences in the 17 issues regardless of whether the issue was framed or how the issue was framed. This result is incompatible with the general expectation that framing issues is usually successful.

Second, most of framing attempts applied to salient issues that have long been considered important and controversial were ineffective. For example, framing attempts on the issues of the "death penalty" (or "capital punishment"); "abortion"; "drug testing"; and "affirmative action programs in employment, college admission, and set-aside" failed to induce a significant shift in the distribution of opinion. In contrast, framing attempts applied to the relatively unfamiliar issues, about which ordinary citizens have little information, worked relatively well. The issue of "logging in the Pacific Northwest" is not on the national political agenda; nor is "funding for the B2 bomber." Both issues were not on the list of national public policy agenda. Few citizens have prior knowledge of these issues and do see their political interests at stake.

Finally, data shows that Americans appear consensual on many issues. They are prochoice(64\% to $71 \%$ ); ${ }^{7}$ against affirmative action(78\% to $83 \%$ ); pro capital punishment

6) More precisely, in the stripped format policy questions were asked to measure if respondents supported or opposed certain policy options. For example, the question of "Are you in favor of or opposed to a large increase in government spending for poor people?" is in the stripped format. In contrast, the same question can be asked in the framed format: "Are you in favor of or opposed to a large increase in government spending to increase opportunities for poor people, even if it means higher taxes?" 
$\langle$ Table 1〉 Summary of Framing Effects

\begin{tabular}{c|c|l|c}
\hline Data Source & $\begin{array}{c}\text { Framing } \\
\text { Format* }\end{array}$ & \multicolumn{1}{|c}{ Issues } & Framing Effects \\
\hline 1989 NES & 3 & The Death Penalty & No Effect \\
\hline 1994 Multi & 4 & Capital Punishment & No Effect \\
\hline 1989 NES & 1 & Abortion & No Effect \\
\hline 1989 NES & 2 & Spending on AIDS & No Effect \\
\hline 1989 NES & 3 & Oil Drilling in the Alaskan Wilderness & No Effect \\
\hline 1989 NES & 3 & Drug Testing & No Effect \\
\hline 1989 NES & 1 & Cooperation with the Russia & No Effect \\
\hline 1989 NES & 3 & Support for the Contra Rebels in Nicaragua & No Effect \\
\hline 1989 NES & 1 & Government Assistance to Blacks & No Effect \\
\hline 1989 NES & 2 & Affirmative Action in Employment & No Effect \\
\hline 1985 NES & 2 & Affirmative Action in Employment & No Effect \\
\hline $1998-9$ Multi & 2 & Street Crime & No Effect \\
\hline $1998-9$ Multi & 1 & Government Spending on Foreign Policy & No Effect \\
\hline $1998-9$ Multi & 4 & Welfare for Immigrants & No Effect \\
\hline $1998-9$ Multi & 4 & Welfare for Single Women with Children & No Effect \\
\hline $1998-9$ Multi & 5 & Affirmative Action in Government Set-Asides & No Effect \\
\hline $1998-9$ Multi & 5 & Affirmative Action in College Admission & No Effect \\
\hline 1994 Multi & 4 & Logging in the Pacific Northwest & Choice Shift \\
\hline 1994 Multi & 2 & Government Job Training for Blacks/All Needy & Choice Shift \\
\hline 1994 Multi & 4 & Allowing Political Rally to the Extreme Group & Choice Reversal \\
\hline 1994 Multi & 4 & Government Responsibility for Blacks/People in Poverty & Choice Reversal \\
\hline $1998-9$ Multi & 4 & Government Spending for the Poor & Choice Reversal \\
\hline $1998-9$ Multi & 2 & Government Spending on Services & Choice Reversal \\
\hline 1989 NES & 3 & Funding for the B2 Bomber & Choice Reversal \\
\hline
\end{tabular}

* Framing format refers to different formats in questions: 1 = Framed vs. Stripped questions; 2 = Frame A vs. Frame B; $3=$ Frame A vs. Frame B vs. Stripped question; $4=$ Frame A vs. Frame B vs. Frame A \& B vs. Stripped question; $5=$ Frame A vs. Frame B vs. Frame C vs. Frames A \& B vs. Frames A \& C vs. Frames B \& C.

(78\% to 84\%); in favor of less government spending on foreign aid(51\% to 60\%); in favor of greater cooperation with the Russia(81\% to 86\%); in favor of increased spending on AIDS(61\% to $65 \%)$; against government assistance to blacks(80\% to $85 \%$ including inbetween position); in favor of oil drilling in the Alaskan wilderness(53\% to58\%); in favor of employee drug testing(67\% to $75 \%$ ); and in favor of welfare programs for immigrants (54\% to $64 \%)$ and single women with children(80\% to $85 \%)$. As expected, framing

7) The differences in percentage are due to different frames. There are some variances in opinions on many issues, but the variances are not statistically significant. 
attempts on these consensual issues created no significant differences in the balance of opinion, regardless of alternative frames or framing formats.

In summary, frames do matter, but they only occasionally shift the balance of opinion. Consequently, frames matter, but it is difficult to say that they are systematically effective across issues. Frames are not effective on salient social issues, nor do they shift the balance of opinion on consensual issues in which the absolute majority of the public shares certain opinions.

\section{Framed versus Stripped Format}

Table 2 illustrates the differences in the opinions in several issues in the framed versus stripped format. As is shown, there are no successful framing attempts. On the issue of "abortion," respondents were generally pro-choice regardless of whether the issue was embedded in the arguments and vocabulary of the opposing camps. On the issue of "relations with the Soviet Union," respondents favored cooperation to a tougher stance, quite independently of whether or not the issue was framed. On the issue of "government assistance to blacks," approximately 9 out of 10 respondents chose the status quo or less assistance regardless of the issue being framed. Finally, on the issue of "government spending on foreign aid" respondents favored the status quo or less spending at 9 to 1 ratio, independently of whether the issue was framed.

In summary, as far as the distribution of opinion is concerned, frames in this format of experiment were completely ineffective. Frames might facilitate the expression of opinion, but they were inconsequential in evaluations of the public policies.

〈Table 2〉 Framing Effects in Framed vs. Striped Questions

\begin{tabular}{l|l|c|c}
\hline \multicolumn{1}{c|}{ Issues } & Chøice Options & Framed Question & Stripped Question \\
\hline Abortion & Pro-choice & $64.1 \%$ & $71.0 \%$ \\
\hline \multirow{4}{*}{ Cooperation with the Russia } & More Cooperation & 41.2 & 48.2 \\
\cline { 2 - 4 } & In-between & 45.1 & 33.0 \\
\cline { 2 - 4 } & Get Tougher & 13.8 & 18.8 \\
\hline \multirow{4}{*}{ Government Assistance to Blacks } & Should Help & 14.5 & 20.1 \\
\cline { 2 - 4 } & In-between & 29.6 & 26.4 \\
\cline { 2 - 4 } & Help Themselves & 55.9 & 53.5 \\
\hline \multirow{2}{*}{$\begin{array}{l}\text { Government Spending } \\
\text { on Foreign Aid }\end{array}$} & More & 11.5 & 7.8 \\
\cline { 2 - 4 } & The same & 37.6 & 31.9 \\
\cline { 2 - 4 } & Less & 51.0 & 60.3 \\
\hline
\end{tabular}

Note: Table shows no significant differences in frequency distributions by framed and stripped frames. This result is based on chi-square test and t-test. 


\section{Alternative Frames Format}

Table 3 illustrates the results in the balance of opinion when alternative frames are presented to the respondents. The table shows that only four of the twelve framing attempts were successful in making significant changes in the distribution of opinion. More precisely, on the issue of "government spending on the B2 bomber," the majority of respondents were in favor, both in "communism" frame $(60 \%)$ and stripped condition $(54 \%)$, while $37 \%$ of the respondents favored it when the issue is framed as in "increasing immoral arms race" frame. ${ }^{8}$ On the issue of "government programs targeted

$\langle$ Table 3〉 Framing Effects in Alternative Frames

\begin{tabular}{|c|c|c|c|c|}
\hline Issues & Choice Options & Frame A & Frame B & $\begin{array}{l}\text { Stripped } \\
\text { Question }\end{array}$ \\
\hline Funding for the B2 Bomber & Favor & $65.5^{\wedge}$ & $36.9^{\wedge} *$ & $54.3^{*}$ \\
\hline \multirow{3}{*}{ Assistance to the Poor } & Increase & $48.8^{*}$ & $37.6^{*}$ & \\
\hline & In-between & $43.1^{\wedge}$ & $53.4^{\wedge}$ & \\
\hline & Decrease & 8.0 & 9.0 & \\
\hline Government Job Training & $\begin{array}{l}\text { Government } \\
\text { Responsibility }\end{array}$ & $28.1^{*}$ & $37.3^{*}$ & \\
\hline $\begin{array}{l}\text { Government Responsibility for } \\
\text { Blacks/People in Poverty }\end{array}$ & $\begin{array}{l}\text { Government } \\
\text { Responsibility }\end{array}$ & $38.7^{* \wedge}$ & $58.8^{*}$ & $46.8^{\wedge}$ \\
\hline \multirow{3}{*}{ Spending on AIDS } & Increase & 60.5 & 65.4 & \\
\hline & The same & 34.0 & 31.5 & \\
\hline & Decrease & 5.5 & 3.1 & \\
\hline Tough on Street Crime & Agree & 49.8 & 48.5 & \\
\hline $\begin{array}{l}\text { Affirmative action in Employment } \\
\text { (1985 NES) }\end{array}$ & Favor & 20.1 & 21.7 & \\
\hline $\begin{array}{l}\text { Affirmative action in Employment } \\
\text { (1989 NES) }\end{array}$ & Favor & 21.7 & 17.0 & \\
\hline The Death Penalty & Favor & 81.6 & 77.6 & 83.5 \\
\hline Oil Drilling in the Alaskan Wilderness & Favor & 57.8 & 55.6 & \\
\hline Drug Testing & Favor & 74.5 & 70.7 & 67.4 \\
\hline \multirow{3}{*}{$\begin{array}{l}\text { Support for the Contra Rebels } \\
\text { in Nicaragua }\end{array}$} & Increase & 15.7 & 12.0 & 9.4 \\
\hline & The Same & 45.7 & 51.7 & 46.0 \\
\hline & Decrease & 38.6 & 36.3 & 44.6 \\
\hline
\end{tabular}

Note: $1 .^{*}$ indicates $p<.05$. This result is based on t-test. For instance, in the first issue (i.e., Funding for the B2 Bomber) frequencies in Frames A \& B are significantly different (indicated by ${ }^{\wedge}$ ) and frequencies in Frame B and Stripped question are significantly different (indicated by *); but frequencies in Frame A and Stripped questions are not significantly different. 2. Table shows that the respondents in the four issues chose significantly different policy option because of differently framed questions. 
for the poor," alternative frames shifted opinions: respondents were more likely to support for the poor when the budget deficit was mentioned than when they were reminded that the poor did not really need the help. On the issue of "government job training programs," $37 \%$ of respondents favored the program "for all needy," while only $28 \%$ favored it for "blacks."

In contrast, on the issues of "affirmative action programs in employment," the "death penalty," "oil drilling in the Alaskan wilderness," "drug testing," and "support for the Contra rebels in Nicaragua," the absolute majority of the respondents took certain issue position regardless of how the issue was framed. None of the framing attempts on these issues was effective in shifting the balance of opinion.

\section{Competing Frames Format}

Tables 4 and 5 show that framing effects occurred in three of the 8 framing attempts. First, policy preferences on "logging in the Pacific Northwest" were significantly changed in a pair of no argument and opposing argument("against logging to preserve the wildness and natural resources"), but not in other pairs of frames.

Second, framing effects in the issues of "whether to increase government spending for the poor" (POOR) and "whether to allow an extremist group to hold political rally" (RALLY) were robust. The magnitude of changes in choice outcomes by the alternative frames was sweeping in both issues. Choice reversals occurred for both issues: The minority in the default condition was the majority in other frames. In RALLY, $45 \%$ of the respondents in default condition provided with neither supporting("given the importance of free speech") nor opposing argument("given the risk of violence") agreed to allow the extremist groups to hold political rally. However, $84 \%$ of the respondents provided with the supporting argument and $57 \%$ of the respondents provided with the opposing argument agreed. In POOR, 47\% of the respondents in default condition agreed to increase government spending for the poor while 69\% with the supporting argument ("to increase opportunities for poor people, so they can have a better chance of getting ahead of life") and 57\% with the opposing argument("even if it means higher taxes") agreed.

A curious result in these two issues is that the percentage of agreement in default group is lower than that in the group with the opposing argument. This means that individuals who would "disagree" in default condition "agreed" in spite of the presence of

8) See Appendix for exact question wordings and frames. 
$\langle$ Table 4〉 Framing Effect in Competing Frames

\begin{tabular}{|c|c|c|c|c|c|}
\hline Issues & $\begin{array}{l}\text { Choice } \\
\text { Options }\end{array}$ & Frame A & Frame B & $\begin{array}{l}\text { Frame } \\
\text { A \& B }\end{array}$ & $\begin{array}{l}\text { Stripped } \\
\text { Question }\end{array}$ \\
\hline Logging in Pacific Northwest & Favor & $35.4^{*}$ & 33.6 & 29.3 & $28.0^{*}$ \\
\hline $\begin{array}{l}\text { Government Spending for } \\
\text { the Poor }\end{array}$ & Favor & $46.5^{* \wedge}$ & $69.4^{\wedge}$ & $67.2^{*}$ & $57.4^{\wedge}$ \\
\hline $\begin{array}{l}\text { Allowing Political Rally } \\
\text { to the Extreme Group }\end{array}$ & Favor & $44.9^{*}$ & $84.3^{*}$ & $74.8^{*}$ & $57.2^{*}$ \\
\hline Capital Punishment & Favor & 81.8 & 80.5 & 78.0 & 78.8 \\
\hline Welfare for Immigrants & Favor & 55.8 & 56.1 & 64.2 & 53.8 \\
\hline $\begin{array}{l}\text { Welfare for Women } \\
\text { with Children }\end{array}$ & Favor & 84.7 & 82.0 & 79.8 & 81.9 \\
\hline
\end{tabular}

Note: $1{ }^{\wedge *}$ indicates $p<.05$. This result is based on t-test. 2 . Table shows that the respondents in the three issues chose significantly different policy option because of differently framed questions.

〈Table 5〉 Framing Effect in Competing Frames on Affirmative Action Programs

\begin{tabular}{l|c|c}
\hline \multicolumn{1}{c|}{ Frames } & Set-Asides & College Admission \\
\hline $\begin{array}{l}\text { (1) Affirmative Action Programs (AAP) are } \\
\text { necessary because of continuing racial } \\
\text { inequality }\end{array}$ & 45.7 & 40.2 \\
\hline $\begin{array}{l}\text { (2) AAP hurt blacks those who succeed } \\
\text { without government help }\end{array}$ & 52.0 & 51.6 \\
\hline $\begin{array}{l}\text { (3) AAP cater too much to the complaints of } \\
\text { blacks }\end{array}$ & 56.0 & 43.0 \\
\hline (1) \&(2) & 46.6 & 49.0 \\
\hline (1) \& (3) & 53.8 & 47.3 \\
\hline (2) \& (3) & 55.5 & 53.9 \\
\hline
\end{tabular}

Note: Table shows no significant differences in frequency distributions by framed and stripped frames. This result is based on $t$-test.

the "opposing" frame. Furthermore, more individuals "agreed" in the cases where both the supporting and opposing arguments were provided than in the cases when no argument was provided. This means that, once again, the opposing argument was ineffective. More precisely, the opposing frame led many individuals to shift to the opposite side of the argument that the frame was supposed to stimulate. These results will be elaborated on in the next section.

Third, policy preferences on "whether to allow capital punishment," "whether immigrants have the right to welfare," and "whether to provide welfare for single women with children" showed no shift in responses to the different frames. Regardless of supporting or opposing arguments, approximately 4 out of 5 respondents favored capital punishment; about 3 out of 5 respondents favored welfare programs for the 
immigrants; and 4 out 5 respondents favored welfare programs for women with children. These results are also discussed in the next section.

Finally, some comments about the lack of framing effects on the issue of affirmative action programs as shown in Tables 3, 4 and 5. As Nelson(2004) puts it, "affirmative action is a modern classic in the annals of framing"(589). Framing effects are known to be evident in racial issues because people are vulnerable to how the questions are phrased and which aspect of the issue is emphasized (Fine 1992; Kinder and Sanders1990; Sniderman et al. 1993; Gamson 1992; Gamson and Modigliani 1987). Thus failures of framing attempts in affirmative action programs in the data sets examined seem inconsistent with standard views. From the perspective of the study on racial attitudes, this is a noticeable null finding, which deserves further research. It might be that this result is related to framing tactics and/or the rhetoric adopted in the studies. In contrast with the successful frames used in $\operatorname{Stoker}(1998)^{9)}$ and Nelson(2004), ${ }^{10)}$ the frames in the 1994 and1998-9 MI S and in the 1985 and 1989 NES may not be tailored narrowly enough to explicate concrete situations to which affirmative action programs are applied. ${ }^{11)}$

\section{Explaining Non-Framing Effects}

The lack of framing effects in the 17 issues could be written off as simply the instrumental failures in identifying appropriate frames in public discourse and/or

9) Stoker(1998) administered an experiment, in which three different affirmative action questions, each concerning the implementation of a racial quota in hiring, were courted. The first question was context-free: "Do you think that large companies should be required to give a certain number of jobs to blacks, or should the government stay out of this?" The second question defines the policy as one that would be undertaken in companies where "blacks are underrepresented," and the third defines the policy as one that would be introduced in companies "with employment policies that discriminate against blacks." The results show that the first and second frames garner less support than the third frames. Thus, people endorse a hiring quota if it is narrowly tailored to discriminatory hiring practices.

10) Nelson(2004) manipulated the institutional role assignment framing rhetoric with pro and con frames of: "Personally, I feel that the mission of a university is to reward excellence," and "It is entirely appropriate for colleges and universities to make every effort to help minorities obtain a higher education." The result shows that opposition to affirmative action was magnified when "reward excellence" was emphasized rather than "opportunities for disadvantaged minorities."

11) The three frames contrasted were "Affirmative action programs(AAP) are necessary because of continuing racial inequality"; "AAP hurt those blacks who succeed without government help"; and "AAP cater too much to the complaints of blacks." 
selecting equally effective rival frames. Identifying proper frames must be difficult. This is because, as Kinder and Nelson(1990) claim, "framing is an ongoing and natural process, which is replicated closely or distantly by the framing experiments reported here"(27). However, at stake in both the MIS and the NES Pilot studies was testing the claim that frames shift the balance of opinion. Concerning the efforts to identify the proper frames in the 1989 NES Pilot Study, Nelson and Kinder(1996) as primary investigators state:

We constructed these alternative question frames carefully, hoping to mimic the rival frames prevailing in contemporary elite discourse. By reenacting public discourse within a controlled experiment, we hope to learn about how changes in public opinion are induced by changes in the setting beyond the survey, in the everyday process of public discussion. Our aim was to operate within the actual rhetorical boundaries of each issue culture by presenting popular frames rather then esoteric or obscure ones. To identify such frames, we relied on Gamson's work; where that offered us no guidance(in the case of public debate on AIDS policy), we substituted our own observations of media coverage(1059).

The principal investigators of the MIS must have exerted the same efforts to identify the proper frames in public discourse. Considering these efforts, a 8:17 ratio vis- $\dot{a}-v i s$ the successful and failed framing attempts must not have been an expected outcome by the investigators of the studies.

Once excluding the instrumental failures, the failed framing attempts might be ascribed to the failures of the theories of framing effects that guide and design theses studies. It seems naive to postulate, as framing theories posit, that exposing individuals to the frames leads them in the desired direction. The findings reported in this paper show that a mere exposure to the frames is ineffective. Respondents facing a frame that may be incongruent with their preexisting values do not change their opinions. And the frame presented does not always prevail over the alternative frame. In short, in many issues accessibility is insufficient for inducing framing effects. Moreover, when people hold strong attitudes on the issue or when the associative strength is strong in certain object-evaluations, framing attempts are less likely to induce a change in opinion.

In another respect, the agenda status of an issue seems matter. Some issues are consensual while others are controversial. Public opinions on the consensual issues seem more stable and consistent than on the controversial issues. As a result, framing attempts on the consensual issues are less effective than are those on the controversial 
issues. Capital punishment, welfare for immigrants, welfare for single women with children, street crime, government spending on foreign aid, and affirmative action in college admission and set-asides programs were consensual issues rather than controversial ones. In addition, in theses issues many respondents feel more comfortable than ambivalent or value conflicted. It seems that citizens are unlikely to be susceptible to the frames on the issues in which values and expectations have long been conflicted, yet in another respect a certain consensus is established.

\section{Concluding Remarks}

The failed framing attempts in four data sets are documented. Framing effects are ambiguous on many issues. And they are not as robust as is often expected. Ordinary citizens are not at all ideological in Conversian terms, but are they competent in making decisions consistent with their value system. In other words, most citizens might be inconsistent decision makers, but they are not be easily manipulated by political frames. Furthermore, the mental mechanisms that underlie framing effects appear more complex than the current theories posit. The findings reported in this article suggest that framing theories need to be extended, refined and explicated.

This article demonstrated that although framing of issues is a central feature in politics, the determinants of framing effects have not yet been fully examined. Further research is needed to better explain how and when framing effects occur, and which policy issues are likely to be more sensitive to framing effects. We need a better understanding of the conditional variability of framing effects across issues. 


\section{REFERENCES}

Alvarez, R. Michael, and John Brehm. Hard Choices, Easy Answers: Values, Information, and American Public Opinion. New Jersey: Princeton University Press, 2002.

Chong, Dennis. "How People Think, Reason, and Feel about Rights and Liberties." American Journal of Political Science 37(3):867-99, 1993.

Ditto, Peter H., and D.F. Lopez. "Motivated Skepticism: Use of Differential Decision Criteria for Preferred and Nonpreferred Conclusions." Journal of Personality ad Social Psychology 63(4):568-584, 1992.

Druckman, James N. "Political Preference Formation: Competition, Deliberation, And the (Ir)relevance of Framing Effects.” American Political Science Review 98(4): 671-86, 2004.

Druckman, James N. "The Implications of Framing Effects for Citizen Competence." Political Behavior 23(3):225-256, 2001a.

Druckman, James N. "On the Limits of Framing Effects." Journal of Politics 63:10411106, $2001 b$.

Druckman, James N., and Kjersten R. Nelson. "Framing and Deliberation." American Journal of Political Science 47:727-44, 2003.

Druckman, James N., and Arthur Lupia. "Preference Formation." Annual Review of Political Science 3:1-24, 2000.

Eagley Alice H. and Shelly Chaiken. The Psychology of Attitudes. Harcourt Brace Javanovich, Inc, 1993.

Entman, Robert M. "Framing Toward Clarification of a Fractured Paradigm." Journal of Communication 43:51-58, 1993.

Entman, Robert M., and Rojecki A. The Black Image in the White Mind: Media and Race in America. Chicago: University of Chicago Press, 2000.

Fagley, Russle H., and Paul M. Miller. "Framing Effects and Arenas of Choice." Organizational Behavior and Human Decision Processes 71(Sep.):353-73, 2003.

Fazio, Russle H., and Michael A. Olson. "Implicit Measures in Social Cognition Research." Annual Review of Psychology 54(Feb.):287-327, 2003.

Fazio, Russel H. "Attitudes as Object-Evaluation Associations: Determinants Consequences, and Correlates of Attitude Accessibility." In Attitude Strength: Antecedents and Consequences, ed. Richard E. Petty, and Jon A. Krosnick. Mamahwah, NJ: Lawrence Erlbaum Associates, Publishers, 1995. 
Feldman, Stanley, and John R. Zaller. "The Political Culture of Ambivalence Ideological Responses to the Welfare State." American Journal of Political Science 36:268-307, 1992.

Fine, Terri Susan. "The Impact of Issue Framing on Public Opinion Toward Affirmative Action Programs." Social Science Journal 29:323-34, 1992.

Gamson, William A. Talking Politics. New York: Cambridge University Press, 1992.

Gamson, William A., and Andre Modigliani. "The Changing Culture of Social Welfare Policy.” In Research in Political Sociology, vol.3, ed, Richard D.Braugart. Greenwich. CT, JAI, 1987.

Gilens, Martin. "Racial Attitudes and Opposition to Welfare." Journal of Politics 57:994-1014, 1995.

Hochschild, Jennifer L. What's Fair? American Beliefs about Distributive Justice. Cambridge: Harvard University Press, 1981.

Iyengar, Shanto. Is Anyone Responsible? How Television Frames Political Issues. Chicago: University of Chicago Press, 1991.

Iyengar, Shanto, and Donald Kinder. News that Matters. Chicago: University of Chicago Press, 1987.

Jacoby, William G. "Issue Framing and Public Opinion on Government Spending." American Journal of Political Science 33(4):750-67, 2000.

Kahneman, Daniel, Paul Slovic, and Amos Tversky. Judgment under Uncertainty: Heuristics and Biases. NY: Cambridge University Press, 1982.

Kahneman, Daniel, and Amos Tversky. ed. Choices, Values, and Frames. Cambridge: Cambridge University Press, 2000.

Kinder, Donald R., and Thomas E. Nelson. "Experimental Investigations of Opinion frames and Survey Responses: A Report to the National Election Studies Board." Center for Political Studies, Institute for Social Research, University of Michigan. Technical Report to the National Election Studies Board, 1990.

Kinder, Donald R., and Lynn M. Sanders. "Mimicking Political Debate with Survey Questions: The case of White Opinion on Affirmative Action." Social Cognition 8:71-103, 1990.

Kinder, Donald R., and Lynn M. Sanders. Divided by Color: Racial Politics and Democratic Ideals. Chicago: University of Chicago Press, 1996.

Kinder, Donald R., and Nicholas Winter. "Exploring the Racial Divide: Blacks, Whites, and Opinion on National Policy." American Journal of Political Science 45:43956, 2001. 
Kinder, Donald R. "Communication and Politics in the Age of Information." In Oxford Handbook of Political Psychology. ed. Sears, David O., Leonie Huddy, and Robert Jervis. NY: Oxford University Press, 2003.

Kmenta, Jan. Elements of Econometrics. Michigan: The University of Michigan Press, 2000.

Koch, Jeffrey W. "Political Rhetoric and Political Persuasion: The Changing Structure of Citizens' References on Health Insurance during Policy Debate." Public Opinion Quarterly 62(2):209-229, 1998.

Kuklinski, James H. ed. Thinking About Political Psychology. NY: Cambridge University Press, 2002.

Kuklinski, James H., Paul J. Quirk, Jennifer Jerit, and Robert F. Rich. "Misinformation and Currency of Democratic Citizenship.” Journal of Politics 62:790-816, 2001.

Kuklinski, James H., and Norman L. Hurley. "It's a Matter of Interpretation." In Political Persuasion and Attitude Change, ed. Mutz, Diana M., Paul .M. Sniderman, and E. Brody. Ann Arbor: University of Michigan Press, 1996.

Kuhberger, Anton, Michael Schulte-Mecklenbeck, and Josef Perner. "The Effects of Framing, Reflection, Probability, and Payoff on Risk Preference in Choice Tasks." Organizational Behavior and Human Decision Processes 78(June): 204-31, 1999.

Kuhberger, Anton. "The Influence of Framing on Risky Decisions." Organizational Behavior and Human Decision Processes 75(July):23-55, 1998.

Laswell, Harold. "The structure and function of communication in society." In The Communication of Ideas. ed. Lyman Bryson. Harper: New York, 1948.

Levin, Irwin P., Sandra L. Schneider, Gary J. Gaeth. "All Frames Are Not Created Equal: A Typology and Critical Analysis of Framing Effects." Organizational Behavior and Human Decision Processes 76(2):149-188, 1998.

Lodge, Milton. "Toward a Procedural Model of Candidate Evaluation." In Political Judgment: Structure and Process. ed. Milton Lodge and Katheleen M. McGraw. Ann Arbor: The University of Michigan Press, 1995.

Lodge, Milton, and Charles Taber. "Three Steps toward a Theory of Motivated Reasoning." In Elements of Reason: Understanding and Expanding the Limits of Political Rationality. ed. Arthur Lupia, Mathew D. McCubbins, and Samuel L. Popkin. New York: Cambridge University Press, 2000.

Lupia, Arthur. "Deliberation Disconnected: What it takes to Improve Civic Competence." Law and Contemporary Problems 65:133-150, 2002. 
Nelson, Thomas E. "Policy Goals, Public Rhetoric, and Political Attitudes." Journal of Politics 66(2):581-605, 2004.

Nelson, Thomas E., Zoe M. Oxley, and Rosalee A. Clawson. "Toward a Psychology of Framing effects." Political Behavior 19:221-246, 1997.

Nelson, Thomas E., and Zoe M. Oxley. "Issue Framing Effects and Belief Importance and Opinion." Journal of Politics 61:1040-1067, 1999.

Nelson, Thomas E., and Donald R. Kinder. "Issue Frames and Group-Centrism in American Public Opinion.” Journal of Politics 58(4):1055-78, 1996.

Sears, David O., and Jack Citrin. Tax Revolt. Cambridge, Mass: Harvard University Press, 1985.

Smith, Tom W. "That Which We Call Welfare by Any other Name Would Smell Sweeter: An Analysis of the Impact of Question Wording on Response Patterns." Public Opinion Quarterly 51:75-83, 1987.

Sniderman, Paul M., and Sean M. Theriault. "The Structure of Political Argument and the Logic of Issue Framing." In Studies in Public Opinion: Attitudes, Nonattitudes, Measurement Error, and Change, eds. Willem E. Saris and Paul M. Sniderman. Princeton: Princeton University Press, 2004.

Sniderman, Paul M., and Thomas L. Piazza. The Scar of Race. Cambridge, Mass.: Harvard University Press, 1993.

Sniderman, Paul M., Richard A. Brody, and Phillip E. Tetlock. Reasoning and Choice: Explorations in Political Psychology. Cambridge: Cambridge University Press, 1991.

Stoker, Laura. "Understanding Whites' Resistance to Affirmative Action: The Role of Principled Commitments and Racial Prejudice." In Perception and Prejudice: Race and Politics in the United States, ed. Hurwitz, Jon, and Mark Peffley. New Haven: Yale University Press, 1998.

Tversky, Amos, and Daniel Kahneman. "The framing of decisions and the Psychology of Choice." Science 211(January):453-58, 1981.

Tversky, Amos, and Daniel Kahneman. "Rational Choice and the Framing of Decisions." In Rational Choice, ed. Robin M. Hogarth and Melvin W. Reder. Chicago: University of Chicago Press, 1987.

Zaller, John A. "Experimental Tests of the Question-Answering Model of the Mass Survey Response." Center for Political Studies, Institute for Social Research, University of Michigan. Technical Report to the National Election Studies Board, 1990.

Zaller, John A. The Nature and Origins of Mass Opinion. New York: Cambridge University Press, 1992. 


\section{APPENDIX}

\section{Multi Investigator Survey}

\section{Death Penalty}

Question was asked in one of four versions to determine the effect of providing a rationale for supporting or opposing positions on capital punishment. The value of the random number variable 'rcpv' determined which version of the question each respondent was asked.

\section{Text of the Question}

Some people support the death penalty...

'rcpv' = 1: ...for persons convicted of murder because justice is served when these criminals are forced to give "an eye for an eye."

'rcpv' = 2: (NO REASON GIVEN)

'rcpv' $=3$ : ... for persons convicted of murder because justice is served when these criminals are forced to give "an eye for an eye."

'rcpv' = 4: (NO REASON GIVEN)

Others feel that the death penalty should be abolished...

'rcpv' = 1: ... because it is imposed in a way that discriminates against minorities and poor people.

'rcpv' = 2: (NO REASON GIVEN)

'rcpv' = 3: (NO REASON GIVEN)

'rcpv' $=4$ : ... because it is imposed in a way that discriminates against minorities and poor people.

What about your opinion? Would you say you are strongly in favor of the death penalty, somewhat in favor, somewhat opposed, or strongly opposed to the death penalty?

\section{Logging}

Question was asked in one of four versions to determine the effect of providing a rationale for supporting more or less logging. The value of the random number variable 'rlgv' determined which version of the question each respondent was asked. 


\section{Text of the Question}

Some people feel that there should be more logging in the Pacific Northwest...

'rlgv' $=1$ : ...in order to promote economic growth and prosperity.

'rlgv' = 2: (NO REASON GIVEN)

'rlgv' = 3: ...in order to promote economic growth and prosperity.

'rlgv' = 4: (NO REASON GIVEN)

Others feel that logging should be limited...

'rlgv' $=1$ : ...in order to preserve the wilderness and natural resources.

'rlgv' = 2: (NO REASON GIVEN)

'rlgv' = 3: (NO REASON GIVEN)

'rlgv' $=4:$...in order to preserve the wilderness and natural resources.

What about your opinion? Would you say you are strongly i n favor of more logging, somewhat in favor, somewhat opposed, or strongly opposed to more logging i $\mathrm{n}$ the Pacific Northwest?

\section{Government Job Training}

There are two versions of the question. The content of the random number variable 'rjtv' indicates which version of the question each respondent was asked.

\section{Text of the Question}

As you may know, unemployment among blacks is high. Some people believe that the government in Washington should be responsible for providing job training to them...

'rjtv' $=1:$... because of the historic injustices blacks have suffered.

'rjtv' $=2:$... not because they're black, but because the government ought to help people who are out of work and want to find a job whether they' re white or black.

Other people believe that the government is basically doing as much as it can and that it is now up to...

$$
\begin{aligned}
& \text { 'rjtv' }=1: \text {.. blacks... } \\
& \text { 'rjtv' }=2: \text {...people, white or black, ... }
\end{aligned}
$$

to take care of their own problems.

If you had to choose, would you say it is mostly the responsibility of the government to provide job training for blacks, or is it mostly up to blacks to take care of their own problems? 


\section{Government Responsibility for Blacks/People in Poverty}

The question has three versions, depending on the value of the random number variable 'rpvv'. Depending on the value of this random number variable, blacks are mentioned (or not mentioned) as the target of poverty programs, and in the justification for these programs.

\section{Text of the Question}

Some people believe that the federal government in Washington should...

'rpvv' $=1$ : ... be responsible for improving the social and economic condition of blacks...

'rpvv' $=2:$... be responsible for improving the social and economic conditions of people...

'rpvv' $=3:$... be responsible for improving the social and economic condition of blacks...

...who are born into poverty. They say that...

'rpvv' $=1$ : ... because of the continuing legacy of slavery and discrimination we have a special obligation to help blacks get ahead.

'rpvv' $=2$ : ... we ought to try to make sure that everyone has an equal opportunity to succeed.

'rpvv' $=3:$...we ought to try to make sure that everyone has an equal opportunity to succeed.

Other people believe that the strength of the American way of life is that people should deal with their problems on their own. If you had to choose, would you say the government should take responsibility, or should the government stay out of it?

\section{8-9 Multi Investigater Survey}

\section{Street Crime}

Respondents were randomly assigned 1 of 2 groups depending on the value of 'rp3a' .

\section{Text of the Question}

How much do you agree or disagree with the following statement?

IF 'rp3a' = 1: In dealing with the problem of street crime, it is important for police to protect the rights of those accused of committing a crime, even if this gets in the way of stopping these crimes. 
IF 'rp3a' $=2$ : In dealing with the problem of street crime, it is important for police to do what it takes to stop these crimes, even if this violates the rights of those accused of committing a crime.

Do you agree strongly, agree somewhat, disagree somewhat, or disagree strongly?

\section{Immigrants and Welfare}

Respondents were randomly assigned to 1 of 3 groups depending on value of ' $r v 13$ '. Text of the Question

IF 'rvl3' = 1: Some people say that people from other countries who are living in the United States have a right to receive welfare if they need it.

IF 'rvl3' = 2: Some people say that people from other countries who are living in the United States must express their loyalty to the United States before they can receive welfare.

IF 'rvl3' = 3: Some people say that people from other countries who are living in the United States have a right to receive welfare if they need it.

Others say that people from other countries who are living in the U.S. must express their loyalty to the United States before they can receive welfare.

How do you feel about allowing legal immigrants from other countries, who are here legally, to receive welfare in the U.S.? Are you for or against this?

\section{Women with Children and Welfare}

Respondents were randomly assigned to 1 of 3 groups depending on value of ' $r v 12$ ' Text of the Question

IF 'rvl2' = 1: Some people say that welfare provides a safety net for people who run into bad times.

IF 'rvl2' = 2: Some people say that welfare discourages people from getting ahead on their own.

IF 'rvl2' = 3: Some people say that welfare provides a safety net for people who run into bad times.

Others say that welfare discourages people from getting ahead on their own.

How do you feel about requiring women with children to work at a job in order to stay on welfare?

Are you for or against this? 


\section{Affirmative Action and Set-aside s}

Respondents were randomly assigned to 1 of 6 groups depending on value of 'rvll' Text of the Question

IF 'rvl1' = 1: Some people say that affirmative action programs are necessary because of continuing racial inequality.

IF 'rvl1' = 2: Some people say that affirmative action programs hurt those Blacks who succeed without government help.

IF 'rvll' = 3: Some people say that affirmative action programs cater too much to the complaints of Blacks.

IF 'rvl1' = 4: Some people say that affirmative action programs are necessary because of continuing racial inequality. Others say that affirmative action programs hurt those Blacks who succeed without government help.

IF 'rvl1' = 5: Some people say that affirmative action programs are necessary because of continuing racial inequality. Others say that affirmative action programs cater too much to the complaints of Blacks.

IF 'rvl1' = 6: Some people say that affirmative action programs hurt those Blacks who succeed without government help. Others say that affirmative action programs cater too much to the complaints of Blacks.

When it comes to setting aside a certain number of government construction contracts for businesses that are owned and operated by minorities, are you for or against this?

\section{Affirmative Action and College Admission}

How do you feel about allowing state universities to have flexible admissions standards in order to promote racial diversity? Are you for or against this?

\section{NES Piløt Study}

\section{Death Penalty}

Respondents were randomly assigned to 1 of 3 groups. 


\section{Text of the Question}

Group 1: There is still much controversy about the death penalty in murder cases. Some people favor the death penalty because they believe it deters crime. Others oppose the death penalty because they believe killing another human being is always immoral, even the killing of someone who has committed murder. Do you favor or oppose the death penalty for the crime of murder?

Group 2: There is still much controversy about the death penalty in murder cases. Some people say that murder is so awful a crime that it deserves to be punished by death. Others oppose the death penalty. They say it is unconstitutional because it is $t^{*}$ cruel and unusual punishment”. Do you favor or oppose the death penalty for the crime of murder?

Group 3: Do you favor or oppose the death penalty for the crime of murder?

\section{Abortion}

Respondents were randomly assigned to 1 of 2 groups.

\section{Text of the Question}

Group 1: There has been some discussion about abortion during recent years. Which one of the opinions I am about to read you best agrees with your view on abortion?

Group 2: There has been some discussion about abortion during recent years. Some Americans oppose abortion: they think of themselves as "prolife"; they believe that abortion is murder. Other Americans believe a woman should have the right to an abortion; they think of themselves as "pro choice;" they believe whether or not to have an abortion must be the woman's choice, not the government's. Which one of the opinions I am about to read YOU best agree with your view on abortion:

\section{Spending on Aids}

Respondents were randomly assigned to 1 of 2 groups.

\section{Text of the Question}

Group 1: Our next question deals with the disease AIDS. Some Americans believe that AIDS is a very serious threat to public health, that too 
many people have already died from AIDS and that the government in Washington should spend more money trying to stop the spread of AIDS and taking care of those people who suffer from the disease. Other Americans believe that most people who get AIDS--primarily homosexual men and intravenous drug users --should have been more careful in the first place. If you had a say in making up the federal budget this year. Would you like to see spending increased, decreased, or stay the same for the fight against AIDS?

Group 2: Our next question deals with the disease AIDS. Some Americans believe that AIDS is a very serious threat to public health, that too many people have already died from AIDS and that the government in Washington should spend more money trying to stop the spread of AIDS and taking care of those people who suffer from the disease. Other Americans believe that the government has more important things to spend money on, like cancer research. If you had a say in making up the federal budget this year, would you like to see spending increased, decreased, or stay the same for the fight against AIDS?

\section{Oil Drilling}

Respondents were randomly assigned to 1 of 3 groups.

\section{Text of the Question}

Group 1: There is a lot of talk these days about a plan to allow more drilling for oil on federal lands in Alaska. Some people are opposed to this drilling. They say the Alaskan wilderness should be preserved in its natural state for future generations. Others say the drilling is necessary because the U.S. needs new energy sources to avoid becoming dependent on foreign oil. What is your opinion? Do you favor or oppose?

Group 2: There is a lot of talk these days about a plan to allow more drilling for oil on federal lands in Alaska. Some people are opposed to this drilling. They say there would be no need to drill for oil in Alaska if we made more efficient use of our existing energy resources. Others support the drilling. They say without new sources of oil, working people will be hurt by higher gasoline prices and there will be further layoffs in American factories. What is your opinion? Do you favor or 
oppose drilling new oil fields on federal lands in Alaska?

Group 3: Do you favor or oppose drilling new oil fields on federal lands in Alaska?

\section{Drug Testing}

Respondents were randomly assigned to 1 of 3 groups.

\section{Text of the Question}

Group 1: Some people believe that illegal drugs like heroin and cocaine are the greatest problem facing America today. As one step in dealing with this problem, they favor giving all employers the right to test their workers for use of illegal drugs. Other people oppose such testing as an invasion of privacy. They say that as long as a worker is performing well on the job, employers should not be able to require a drug test. Do you favor or oppose giving all employers the right to test their workers for possible use of illegal drugs?

Group 2: Here is a question about the problem of illegal drugs. As one step in dealing with this problem, some people think all employers should have the right to test their workers for possible use of illegal drugs. Others oppose this kind of testing. As you know, there is a lot of debate in the press on this question of whether employers should have the right to test workers for illegal drugs. Which side of the debate is closer to your view? Do you favor or oppose giving all employers the right to test their workers for possible use of illegal drugs?

Group 3: Do you favor or oppose giving all employers the right to test their workers for the possible use of illegal drugs?

\section{Cooperate with the Russia}

Respondents were randomly assigned to 1 of 2 groups.

\section{Text of the Question}

Group 1: Our next question concerns the relationship between the United States and Russia. Some Americans feel that we should try to cooperate more with Russia, in order to reduce the chances of a nuclear war. Other Americans believe that we should be much tougher in our dealings with Russia because Russian leaders are communists and they still want to take over the world. Do you feel we should try to cooperate 
more with Russia, get tougher in our dealings with Russia, or is your opinion somewhere in between?

Group 2: Our next question concerns the relationship between the United States and Russia. Some Americans feel that we should try to cooperate more with Russia. While others believe that we should be much tougher in our dealings with Russia. Do you feel we should try to cooperate more with Russia, get tougher in our dealings with Russia, or is your opinion somewhere in between?

\section{Aid to the Contras}

Respondents were randomly assigned to 1 of 3 groups.

\section{Text of the Question}

Group 1: Here is another question about foreign policy. As you know, the U.S. has been giving aid to the Contras, a guerilla group that wants to overthrow the Communist government of Nicaragua. Some people say we should stop aid to the Contras because the U.S. has no business in the internal affairs of Nicaragua. Others think the U.S. should continue the aid because the Contras are freedom fighters trying to stop the spread of Communism in Central America. Would you like to see aid to the Contras in Nicaragua increased, decreased, or stay the same?

Group 2: Here is another question about foreign policy. As you know, the U.S. has been giving aid to the Contras, a guerilla group that wants to overthrow the Sandinista government of Nicaragua. Some people say we should stop aid to the Contras because the money could be better spent in the U.S. Others think the U.S. should continue the aid because the Contras are fighting to promote democracy in Central America. Would you like to see aid to the Contras in Nicaragua increased, decreased, or stay the same?

Group 3: Here is another question about foreign policy. Would you like to see aid to the Contras in Nicaragua increased, decreased, or stay the same?

\section{Government Assistance to Blacks}

Respondents were randomly assigned to 1 of 2 groups. 


\section{Text of the Question}

Group 1: Some people feel that the government in Washington should make a special effort to improve the social and economic position of blacks, because blacks still don't have the same opportunities to get ahead as everyone else. Others feel that the government should not make any special effort to help blacks: that blacks should help themselves, just as other groups have done. Do you feel the government should or should not make a special effort to help blacks, or is your opinion somewhere in between?

Group 2: Some people feel that the government in Washington should make a special effort to improve the social and economic position of blacks, while others feel that the government should not make any special effort to help blacks. Do you feel the government should or should not make a special effort to help blacks, or is your opinion somewhere in between?

\section{Affirmative Action and Employments}

Respondents were randomly assigned to 1 of 2 groups.

\section{Text of the Question}

Group 1: Next is a question about whether employers should favor blacks when they decide who to hire and promote. Some people say that because of past discrimination, employers should give preference to qualified blacks. Others disagree, saying that favoring blacks gives them advantages that they haven't really earned. Are you for or against employers favoring blacks when they decide who to hire and promote?

Group 2: Next is a question about whether employers should favor blacks when they decide who to hire and promote. Some people say that because of past discrimination, employers should give preference to qualified blacks. Others disagree, saying that favoring blacks amounts to discrimination against whites. Are you for or against employers favoring blacks when they decide who to hire and promote?

\section{The New Stealth Bomber}

Respondents were randomly assigned to 1 of 3 groups. 


\section{Text of the Question}

Group 1: Here is a question about defense policy. There is much debate over whether the Air Force should build the new Stealth bomber. Some people are against this weapon. They say the Stealth is another costly high-tech weapon system that will probably not work very well. Others believe we need the Stealth bomber. They say the only way to be safe from Russia and the other Communist bloc nations is to make sure we stay a lot stronger than they are. Do you believe the Air Force should go ahead with plans to build the Stealth bomber, or do you think that building the Stealth bomber would be a bad idea?

Group 2: Here is a question about defense policy. There is much debate over whether the Air Force should build the new Stealth bomber. Some people are against this weapon. They say the only way to stop the immorality of the nuclear arms race is for the U.S. to stop building up its nuclear forces. Others believe we need the Stealth bomber. They say that our existing bomber forces are obsolete and need to be modernized. Do you believe the Air Force should go ahead with plans to build the Stealth bomber, or do you think that building the Stealth bomber would be a bad idea?

Group 3: Here is a question about defense policy. Do you believe the Air Force should go ahead with plans to build the Stealth bomber, or do you think that building the Stealth bomber would be a bad idea? 